\title{
Vagal-Immune Interactions Involved in Cholinergic Anti-Inflammatory Pathway
}

\author{
I. ZILA ${ }^{1,2}$, D. MOKRA ${ }^{1,2}$, J. KOPINCOVA ${ }^{1,2}$, M. KOLOMAZNIK ${ }^{1,2}$, M. JAVORKA ${ }^{1,2}$, \\ A. CALKOVSKA ${ }^{1,2}$
}

${ }^{1}$ Department of Physiology, Jessenius Faculty of Medicine in Martin, Comenius University in Bratislava, Martin, Slovakia, ${ }^{2}$ Biomedical Center Martin, Jessenius Faculty of Medicine in Martin, Comenius University in Bratislava, Martin, Slovakia

Received April 12, 2017

Accepted April 21, 2017

\section{Summary}

Inflammation and other immune responses are involved in the variety of diseases and disorders. The acute response to endotoxemia includes activation of innate immune mechanisms as well as changes in autonomic nervous activity. The autonomic nervous system and the inflammatory response are intimately linked and sympathetic and vagal nerves are thought to have anti-inflammation functions. The basic functional circuit between vagus nerve and inflammatory response was identified and the neuroimmunomodulation loop was called cholinergic anti-inflammatory pathway. Unique function of vagus nerve in the anti-inflammatory reflex arc was found in many experimental and pre-clinical studies. They brought evidence on the cholinergic signaling interacting with systemic and local inflammation, particularly suppressing immune cells function. Pharmacological/electrical modulation of vagal activity suppressed TNF-a and other proinflammatory cytokines production and had beneficial therapeutic effects. Many questions related to mapping, linking and targeting of vagal-immune interactions have been elucidated and brought understanding of its basic physiology and provided the initial support for development of Tracey's inflammatory reflex. This review summarizes and critically assesses the current knowledge defining cholinergic anti-inflammatory pathway with main focus on studies employing an experimental approach and emphasizes the potential of modulation of vagally-mediated anti-inflammatory pathway in the treatment strategies.

\section{Key words}

Lipopolysaccharide • Endotoxemia • Autonomic nervous system • Vagus nerve - Cholinergic anti-inflammatory pathway • Inflammatory reflex $\bullet$ Cytokines

\section{Corresponding author}

A. Calkovska, Department of Physiology and Biomedical Center Martin, Jessenius Faculty of Medicine in Martin, Comenius University in Bratislava, Mala Hora 4C, 03601 Martin, Slovakia. E-mail: calkovska@jfmed.uniba.sk

\section{Introduction}

One of the major functions of the immune system is to provide defense against pathogens. Defense response has to be controlled in order to avoid excessive inflammation and successive tissue/organ impairment. Many diseases result from inappropriate inflammatory response characterized by the complex interaction between pro- and anti-inflammatory cytokines, and other inflammatory mediators. On the local level, inflammatory response is mainly controlled through cytokine production by immune cells while systemic inflammatory response is regulated particularly through neuroendocrine mechanisms (Maier et al. 1998, Elenkov et al. 2000). It was clearly shown that inflammatory cytokines signal the brain via the afferent vagus nerve, resulting in fever and causing activation of the stress response including the hypothalamic-pituitary-adrenal axis (Maier et al. 1998), hypothalamic-pituitary-gonadal axis, hypothalamicpituitary-thyroid axis, and the sympathetic nervous system (Elenkov et al. 2000, Bellinger et al. 2008). According to Hasko and Szabo (1998), the sympathetic division of the autonomic nervous system is associated with a dual mode of regulation of inflammatory responses 
and both adrenaline and noradrenaline modulate the release of cytokines and inflammation through adrenergic receptors on immune cells. Last two decades brought a strong interest in modulation of the immune system by autonomic nervous system. Many studies confirmed that the release of tumor necrosis factor (TNF), interleukin (IL)-1 high mobility group box 1 (HMGB1) protein, and other pro- and anti-inflammatory cytokines from immune cells is at least partially regulated through autonomic nervous system (Elenkov et al. 2000, Tracey 2002, Pavlov et al. 2003, Pavlov and Tracey 2004).

The research has been focused particularly on parasympathetic nervous system. It was shown that afferent arm of vagus nerve may sense inflammation in the periphery and relay the signals to the brain, which in turn dampens sickness response (Watkins et al. 1995, Goehler et al. 2000). In 2000 Tracey and coworkers elegantly demonstrated powerful relation between efferent vagus nerve and the innate immune system. Strong link has been discovered and Tracey's experiments established a new concept of the ,inflammatory reflex“ as a well-defined nervous-immune systems interplay regulating inflammation (Borovikova et al. 2000).

\section{The cholinergic anti-inflammatory pathway}

Tracey's experiments clearly showed anti-inflammatory mechanisms mediated by efferent vagus nerve. Pharmacological/electrical stimulation of vagus nerve significantly reduced inflammation in endotoxemic rats while this effect was blocked by vagotomy and atropin administration (Borovikova et al. 2000). The release of acetylcholine following vagus activation inhibited the LPS-induced production of systemic pro-inflammatory cytokines (TNF- $\alpha$, IL-1, 6, 18) in human macrophages, but circulating levels of anti-inflammatory cytokines were not suppressed (Gaykema et al. 1995, Fleshner et al. 1998).

Pavlov et al. (2006) demonstrated that antiinflammatory effect of vagal stimulation cannot be blocked by muscarinic antagonist and these findings show involvement of central muscarinic link in the cholinergic anti-inflammatory pathway. Subsequent studies helped to identify the peripheral structures involved in anti-inflammatory activity. In 2003 Wang and coworkers described a key role of nicotinic receptor and its $\alpha 7$ subunit ( $\alpha 7 \mathrm{nAchR})$ as the main receptor allowing macrophage modulation.
The concept of $\alpha 7 \mathrm{nAchR}$ as a peripheral „immune“ nicotinic component has been subsequently applied in a number of studies confirming attenuation of inflammatory response during vagus nerve stimulation with beneficial effects in sepsis, ischaemia-reperfusion, shock and gastrointestinal inflammation models (Borovikova et al. 2000, Bernik et al. 2002, Guarini et al. 2004, Lubers et al. 2010, Lubers et al. 2011).

In 2006 Huston et al. proposed spleen as a crucial organ, where cytokines production is suppressed by stimulation of vagus. However, considering minimal cholinergic innervation of the spleen in rodents, this concept required revision and disynaptic pathway was suggested by Rosas-Ballina et al. (2008). In this model, vagal preganglionic fibers synapse with postganglionic sympathetic neurons in celiac ganglion subsequently traveling in splenic nerves. Disynaptic model has been extended by recognition of acetylcholine-synthesizing T-cells (Rosas-Ballina et al. 2011, Gautron et al. 2013) where essential $\alpha 7$ nicotinic receptor is located on splenic macrophages. In 2012 Bratton and coworkers critically questioned disynaptic concept. They did not confirm any functional or anatomical connection between vagus and splenic nerves. For explanation of this apparent contradiction, Martelli et al. (2014) have proposed the concept of non-neural link between vagus and splenic sympathetic nerves with $\alpha 7$ nicotinic receptors situated on peripheral terminals of splenic nerves. When $\alpha 7$ subunits are stimulated by acetylcholine released from T-cells, terminals secrete noradrenaline which subsequently binds to $\beta$-adrenergic receptors of splenic macrophages to attenuate TNF- $\alpha$ production. As a mechanism of predicted non-neural communication between vagus and spleen following vagal stimulation, the authors propose a role of mobilized lymphocytes including acetylcholine-synthesizing T-cells (Martelli et al. 2014).

\section{Assessment of cholinergic anti-inflammatory pathway}

Excessive activation of immune system may lead to organ damage/failure in shock, sepsis, trauma and autoimmune diseases. Numerous animal studies demonstrated beneficial outcomes of the cholinergic antiinflammatory pathway stimulation. These effects were achieved by electrical stimulation of vagal fibers and/or by administration of specific muscarinic and $\alpha 7 \mathrm{nAchR}$ agonists. However, for human use, both approaches have 
some limitations. Electrical stimulation is not appropriate in acute situations while pharmacological method is limited because of its specificity, toxic side effects, routes of administration and possible physical addiction (nicotine). Lubbers et al. in series of studies (Lubbers et al. 2010, Lubbers et al. 2011, Lubbers et al. 2013) demonstrated that also physiological stimulation of antiinflammatory pathway, predominantly of its afferent vagal limb by enteral feeding, can reduce cytokines levels and improve organ functions.

Generally, vagal nerve activity and its immunemodulatory effect are difficult to be assessed in human. However, analysis of heart rate variability (HRV) gives a clear idea about autonomic regulation of cardiorespiratory function (Fernandez et al. 2014). Reduced HRV was found in endotoxemic patients (Rassias et al. 2005) and HRV measurement may indicate inverse relationship between inflammation biomarkers and vagal HRV measures also in animal models (Crandall et al. 2000, Matthew et al. 2004, Tateishi et al. 2007). In our recent study, short-term heart rate variability was evaluated as an index of cardiac autonomic control in rats with LPS-induced endotoxemia. Endotoxemia was accompanied by a significant decrease in HRV spectral activity in high-frequency range at maximal body temperature and increased IL- 6 level was present in the cardiac tissue of endotoxemic rats. We concluded that decreased HRV in HF band may indicate a reduced parasympathetic activity in LPS-induced endotoxemia as basic characteristics of altered cardiac control during response to endotoxemia (Zila et al. 2015). In healthy human, low vagal tone was reported in independent association with increased IL-6 and TNF levels (Marsland et al. 2007, Sloan et al. 2007, von Känel et al. 2008, Weber et al. 2010, Tonhajzerova et al. 2013, Visnovcova et al. 2015). Several clinical studies provided evidence on inverse correlation between HRV and inflammatory markers, mostly in immune-mediated diseases, brain injury and cardiovascular diseases (Goldstein et al. 2007, Haensel et al. 2008, Huston and Tracey 2011, Kox et al. 2012). On the contrary, study of Papaioannou et al. (2009) did not report any correlation between IL- 6 and vagal tone suggesting pluripotency of IL-6 possessing both pro-inflammatory and antiinflammatory features at the same time. Kox et al. (2011) also reported no HRV - cytokines association in human endotoxemia. Moreover, because of organ specific vagal outflow (heart versus inflammatory organs) the authors have questioned HRV analysis as an appropriate method to evaluate activation of the cholinergic antiinflammatory pathway (Kox and Pickkers 2015). Anyway, although there is only limited number of studies evaluating anti-inflammatory potential of vagus in human, even with some controversial results, HRV analysis is currently the only available method to assess vagal activity.

\section{Clinical implications}

Most preclinical studies indicate the suppression of systemic or local inflammation via anti-inflammatory pathway has the potential of an effective treatment strategy. Unilateral cervical (Van Westerloo et al. 2005) or subdiaphragmatic vagotomy (Kessler et al. 2006) increased plasma levels of pro-inflammatory cytokines, tissue damage and mortality in sepsis. On the other hand, activation of anti-inflammatory pathway via stimulation of vagus nerve or by $\alpha 7 \mathrm{nAchR}$ agonists clearly demonstrated the effective reduction in cytokine/HMGB1 levels and increased survival rate in sepsis models (Borovikova et al. 2000, Wang et al. 2003). Recent observations indicate the future potential mostly for non-invasive techniques of activation (electroacupuncture) and highlight several pharmacological approaches $(\alpha 7 \mathrm{nAchR}$ agonists, $\beta_{2}$ adrenergic agonists) in inhibition of the initial phase of sepsis minimizing an impact on specific innate immune mechanisms eliminating bacteria (Torres-Rosas et al. 2014, Rosas-Balina et al. 2015, Kanashiro et al. 2017, Pinheiro et al. 2017). Besides sepsis model, the cholinergic anti-inflammatory pathway was reported to be capable in reducing ischemic tissue and organ damage in intestine, heart, brain and kidneys (de Haan et al. 2008, Ottani et al. 2009, Yeboah et al. 2008, Kong et al. 2011).

Anti-inflammatory pathway and its effect on chronic inflammatory diseases of gastrointestinal tract were widely studied in preclinical animal models. Herein, particularly treatment of ulcerative colitis seems to be promising, since both $\alpha 7 \mathrm{nAchR}$ agonists and acetylcholinesterase inhibitors reduced severity of the disease (Miceli and Jacobson 2003, Bai et al. 2009). However, current clinical observations yielded in controversial data, as selective $\alpha 7 \mathrm{nAchR}$ agonists used in treatment of ulcerative colitis and Crohn's disease gave ambiguous results (Nikfar et al. 2010, Kox et al. 2011, Bonaz et al. 2016). Administration of $\alpha 7 \mathrm{nAchR}$ agonists to animals with another chronic inflammatory disease, rheumatoid arthritis, also leads to a significant improvement (Koopman et al. 2011). In the same 
experimental model, stimulation of the vagus nerve ameliorated arthritis symptoms, reduced serum cytokine levels, and protected against joint destruction (Koopman et al. 2014). Recent data also suggest a possible role of cholinergic anti-inflammatory pathway in the prevention of type 1 diabetes mellitus (George et al. 2016). Anti-inflammatory pathway was suggested to be of benefit in heterogenous group of diseases including postoperative ileus, asthma, acute respiratory distress syndrome, as well as cognitive impairments in schizophrenia and Alzheimer's disease (Costes et. al. 2014, Galle-Treger et al. 2016, Pinheiro et al. 2017, Lewis et al. 2017).

\section{Conclusions}

Although better understanding of vagal-immune interactions involved in cholinergic anti-inflammatory pathway would require further insights, at present, well-defined Tracey's concept of vagal-immune communication has been accepted. The current knowledge suggests a huge potential of modulation of a vagally-mediated anti-inflammatory pathway in the treatment strategies.

\section{Conflict of Interest}

There is no conflict of interest.

\section{Acknowledgements}

This work was supported by the project „Centre for Experimental and Clinical Respirology", co-financed from EU sources, and by projects VEGA 1/0469/16, APVV-0235-12 and APVV-15-0075.

\section{References}

BAI A, GUO Y, LU N: The effect of the cholinergic anti-inflammatory pathway on experimental colitis. Scand J Immunol 66: 538-545, 2007.

BONAZ B, SINNIGER V, HOFFMANN D, CLARENÇON D, MATHIEU N, DANTZER C, VERCUEIL L, PICQ C, TROCMÉ C, FAURE P, CRACOWSKI JL, PELLISSIER S: Chronic vagus nerve stimulation in Crohn's disease: a 6-month follow-up pilot study. Neurogastroenterol Motil 28: 948-953, 2016.

BOROVIKOVA LV, IVANOVA S, ZHANG M, YANG H, BOTCHKINA GI, WATKINS LR, WANG H, ABUMRAD N, EATON JW, TRACEY KJ: Vagus nerve stimulation attenuates the systemic inflammatory response to endotoxin. Nature 405: 458-462, 2000.

BELLINGER DL, MILLAR BA, PEREZ S, CARTER J, WOOD C, THYAGARAJAN S, MOLINARO C, LUBAHN C, LORTON D: Sympathetic modulation of immunity: relevance to disease. Cell Immunol 252: 27-56, 2008.

BERNIK TR, FRIEDMAN SG, OCHANI M, DIRAIMO R, SUSARLA S, CZURA CJ, TRACEY KJ: Cholinergic antiinflammatory pathway inhibition of tumor necrosis factor during ischemia reperfusion. J Vasc Surg 36 : 1231-1236, 2002.

BRATTON BO, MARTELLI D, MCKINLEY MJ, TREVAKS D, ANDERSON CR, MCALLEN RM: Neural regulation of inflammation: no neural connection from the vagus to splenic sympathetic neurons. Exp Physiol 97: 1180-1185, 2012.

COSTES LM, VAN DER VLIET J, VAN BREE SH, BOECKXSTAENS GE, CAILOTTO C: Endogenous vagal activation dampens intestinal inflammation independently of splenic innervation in postoperative ileus. Auton Neurosci 185: 76-82, 2014.

CRANDALL CG, ZHANG R, LEVINE BD: Effects of whole body heating on dynamic baroreflex regulation of heart rate in humans. Am J Physiol Heart Circ Physiol 279: H2486-H2492, 2000.

DE HAAN JJ, LUBBERS T, HADFOUNE M, LUYER MD, DEJONG CH, BUURMAN WA, GREVE JW: Postshock intervention with high-lipid enteral nutrition reduces inflammation and tissue damage. Ann Surg 248: 842-848, 2008.

ELENKOV IJ, WILDER RL, CHROUSOS GP, VIZI ES: The sympathetic nerve - an integrative interface between two supersystems: the brain and the immune system. Pharmacol Rev 52: 595-638, 2000.

FERNANDEZ R, NARDOCCI G, NAVARRO C, REYES EP, ACUÑA-CASTILLO C, CORTES PP. Neural reflex regulation of systemic inflammation: potential new targets for sepsis therapy. Front Physiol 5: 489, 2014. 
FLESHNER M, GOEHLER LE, SCHWARTZ BA, MCGORRY M, MARTIN D, MAIER SF, WATKINS LR: Thermogenic and corticosterone responses to intravenous cytokines (IL-1beta and TNF-alpha) are attenuated by subdiaphragmatic vagotomy. J Neuroimmunol 86: 134-141, 1998.

GALLE-TREGER L, SUZUKI Y, PATEL N, SANKARANARAYANAN I, ARON JL, MAAZI H, CHEN L, AKBARI O: Nicotinic acetylcholine receptor agonist attenuates ILC2-dependent airway hyperreactivity. Nat Commun 7: 13202, 2016.

GAUTRON L, RUTKOWSKI JM, BURTON MD, WEI W, WAN Y, ELMQUIST JK: Neuronal and nonneuronal cholinergic structures in the mouse gastrointestinal tract and spleen. J Comp Neurol 521: 3741-3767, 2013.

GAYKEMA RP, DIJKSTRA I, TILDERS FJ: Subdiaphragmatic vagotomy suppresses endotoxininduced activation of hypothalamic corticotropin-releasing hormone neurons and ACTH secretion. Endocrinology 136: 4717-4720, 1995.

GEORGE JA, BASHIR G, QURESHI MM, MOHAMED YA, AZZI J, AL-RAMADI BK, FERNÁNDEZCABEZUDO MJ: Cholinergic stimulation prevents the development of autoimmune diabetes: evidence for the modulation of Th17 effector cells via an IFN $\gamma$-dependent mechanism. Front Immunol 7: 419, 2016.

GOEHLER LE, GAYKEMA RP, HANSEN MK, ANDERSON K, MAIER SF, WATKINS LR: Vagal immune-tobrain communication: a visceral chemosensory pathway. Auton Neurosci 85: 49-59, 2000.

GOLDSTEIN RS, BRUCHFELD A, YANG L: Cholinergic anti-inflammatory pathway activity and high mobility group box-1 (HMGB1) serum levels in patients with rheumatoid arthritis. Mol Med 13: 210-215, 2007.

GUARINI S, CAINAZZO MM, GIULIANI D, MIONI C, ALTAVILLA D, MARINI H, BIGIANI A, GHIARONI V, PASSANITI M, LEONE S, BAZZANI C, CAPUTI AP, SQUADRITO F, BERTOLINI A: Adrenocorticotropin reverses hemorrhagic shock in anesthetized rats through the rapid activation of a vagal anti-inflammatory pathway. Cardiovasc Res 63: 357-365, 2004.

HAENSEL A, MILLS PJ, NELESEN RA, ZIEGLER MG, DIMSDALE JE: The relationship between heart rate variability and inflammatory markers in cardiovascular diseases. Psychoneuroendocrinology 33: 1305-1312, 2008.

HASKO G, SZABO C: Regulation of cytokine and chemokine production by transmitters and co-transmitters of the autonomic nervous system. Biochem Pharmacol 56: 1079-1087, 1998.

HUSTON JM, OCHANI M, ROSAS-BALLINA M, LIAO H, OCHANI K, PAVLOV VA, GALLOWITSCH-PUERTA M, ASHOK M, CZURA CJ, FOXWELL B, TRACEY KJ, ULLOA L: Splenectomy inactivates the cholinergic antiinflammatory pathway during lethal endotoxemia and polymicrobial sepsis. $J$ Exp Med 203: 1623-1628, 2006.

HUSTON JM, TRACEY KJ: The pulse of inflammation: heart rate variability, the cholinergic anti-inflammatory pathway and implications for therapy. J Intern Med 269: 45-53, 2011.

KANASHIRO A, SÔNEGO F, FERREIRA RG, CASTANHEIRA FV, LEITE CA, BORGES VF, NASCIMENTO DC, CÓLON DF, ALVES-FILHO JC, ULLOA L, CUNHA FQ: Therapeutic potential and limitations of cholinergic anti-inflammatory pathway in sepsis. Pharmacol Res 117: 1-8, 2017.

KESSLER W, TRAEGER T, WESTERHOLT A, NEHER F, MIKULCAK M, MÜLLER A, MAIER S, HEIDECKE $\mathrm{CD}$ : The vagal nerve as a link between the nervous and immune system in the instance of polymicrobial sepsis. Langenbecks Arch Surg 391: 83-87, 2006.

KONG SS, LIU JJ, HWANG TC, YU XJ, LU Y, ZANG WJ: Tumour necrosis factor-alpha and its receptors in the beneficial effects of vagal stimulation after myocardial infarction in rats. Clin Exp Pharmacol Physiol 38: 300-306, 2011.

KOOPMAN FA, STOOF SP, STRAUB RH, VAN MAANEN MA, VERVOORDELDONK MJ, TAK PP: Restoring the balance of the autonomic nervous system as an innovative approach to the treatment of rheumatoid arthritis. Mol Med 17: 937-948, 2011.

KOOPMAN FA, SCHUURMAN PR, VERVOORDELDONK MJ, TAK PP. Vagus nerve stimulation: a new bioelectronics approach to treat rheumatoid arthritis? Best Pract Res Clin Rheumatol 28: 625-635, 2014.

KOX M, RAMAKERS BP, POMPE JC, VAN DER HOEVEN JG, HOEDEMAEKERS CW, PICKKERS P: Interplay between the acute inflammatory response and heart rate variability in healthy human volunteers. Shock $\mathbf{3 6}$ : 115-120, 2011. 
KOX M, VROUWENVELDER MQ, POMPE JC, VAN DER HOEVEN JG, PICKKERS P, HOEDEMAEKERS CW: The effects of brain injury on heart rate variability and the innate immune response in critically ill patients. J Neurotrauma 29: 747-755, 2012.

KOX M, PICKKERS P: Modulation of the innate immune response through the vagus nerve. Nephron 131: 79-84, 2015.

LEWIS AS, VAN SCHALKWYK GI, BLOCH MH. Alpha-7 nicotinic agonists for cognitive deficits in neuropsychiatric disorders: A translational meta-analysis of rodent and human studies. Prog Neuropsychopharmacol Biol Psychiatry 75: 45-53, 2017.

LUBBERS T, DE HAAN JJ, LUYER MD, VERBAEYS I, HADFOUNE M, DEJONG CH, BUURMAN WA, GREVE JW: Cholecystokinin/Cholecystokinin-1 receptor-mediated peripheral activation of the afferent vagus by enteral nutrients attenuates inflammation in rats. Ann Surg 252: 376-382, 2010.

LUBBERS T, DE HAAN JJ, HADFOUNE M, ZABEAU L, TAVERNIER J, ZHANG Y, GRUNDY D, GREVE JW, BUURMAN WA: Chylomicron formation and glucagon-like peptide 1 receptor are involved in activation of the nutritional anti-inflammatory pathway. J Nutr Biochem 22: 1105-1111, 2011.

LUBBERS T, KOX M, DE HAAN JJ, GREVE JW, POMPE JC, RAMAKERS BP, PICKKERS P, BUURMAN WA: Continuous administration of enteral lipid- and protein-rich nutrition limits inflammation in a human endotoxemia model. Crit Care Med 41: 1258-1265, 2013.

MAIER SF, GOEHLER LE, FLESHNER M, WATKINS LR: The role of the vagus nerve in cytokineto-brain communication. Ann N Y Acad Sci 840: 289-300, 1998.

MARSLAND AL, GIANAROS PJ, PRATHER AA, JENNINGS JR, NEUMANN SA, MANUCK SB: Stimulated production of proinflammatory cytokines covaries inversely with heart rate variability. Psychosom Med 69: 709-716, 2007.

MARTELLI D, MCKINLEY MJ, MCALLEN RM: The cholinergic anti-inflammatory pathway: a critical review. Auton Neurosci 182: 65-69, 2014.

MATTHEW CB, BASTILLE AM, GONZALEZ RR, SILS IV: Heart rate variability as an index of physiological strain in hyperthermic and dehydrated rats. $J$ Therm Biol 29: 211-219, 2004.

OTTANI A, GIULIANI D, MIONI C, GALANTUCCI M, MINUTOLI L, BITTO A, ALTAVILLA D, ZAFFE D, BOTTICELLI AR, SQUADRITO F, GUARINI S: Vagus nerve mediates the protective effects of melanocortins against cerebral and systemic damage after ischemic stroke. J Cereb Blood Flow Metab 29: 512-523, 2009.

MICELI PC, JACOBSON K: Cholinergic pathways modulate experimental dinitrobenzene sulfonic acid colitis in rats. Auton Neurosci 105: 16-24, 2003.

NIKFAR S, EHTESHAMI-ASHAR S, RAHIMI R, ABDOLLAHI M: Systematic review and meta-analysis of the efficacy and tolerability of nicotine preparations in active ulcerative colitis. Clin Ther 32: 2304-2315, 2010.

PAPAIOANNOU VE, DRAGOUMANIS C, THEODOROU V, GARGARETAS C, PNEUMATIKOS I: Relation of heart rate variability to serum levels of C-reactive protein, interleukin 6, and 10 in patients with sepsis and septic shock. J Crit Care 24: 625, 2009.

PAVLOV VA, WANG H, CZURA CJ, FRIEDMAN SG, TRACEY KJ: The cholinergic anti-inflammatory pathway: a missing link in neuroimmunomodulation. Mol Med 9: 125-134, 2003.

PAVLOV VA, TRACEY KJ: Neural regulators of innate immune responses and inflammation. Cell Mol Life Sci 61: 2322-2331, 2004.

PAVLOV VA, OCHANI M, GALLOWITSCH-PUERTA M, OCHANI K, HUSTON JM, CZURA CJ, AL-ABED Y, TRACEY KJ: Central muscarinic cholinergic regulation of the systemic inflammatory response during endotoxemia. Proc Natl Acad Sci US A 103: 5219-5223, 2006.

PINHEIRO NM, SANTANA FP, ALMEIDA RR, GUERREIRO M, MARTINS MA, CAPERUTO LC, CÂMARA NO, WENSING LA, PRADO VF, TIBÉRIO IF, PRADO MA, PRADO CM: Acute lung injury is reduced by the $\alpha 7$ nAChR agonist PNU-282987 through changes in the macrophage profile. FASEB J 31: 320-332, 2017.

RASSIAS AJ, HOLZBERGER PT, GIVAN AL, FAHRNER SL, YEAGER MP: Decreased physiologic variability as a generalized response to human endotoxemia. Crit Care Med 33: 512-519, 2005. 
ROSAS-BALLINA M, OCHANI M, PARRISH WR, OCHANI K, HARRIS YT, HUSTON JM, CHAVAN S, TRACEY KJ: Splenic nerve is required for cholinergic antiinflammatory pathway control of TNF in endotoxemia. Proc Natl Acad Sci U S A 105: 11008-11013, 2008.

ROSAS-BALLINA M, OLOFSSON PS, OCHANI M, VALDÉS-FERRER SI, LEVINE YA, REARDON C, TUSCHE MW, PAVLOV VA, ANDERSSON U, CHAVAN S, MAK TW, TRACEY KJ: Acetylcholine-synthesizing T cells relay neural signals in a vagus nerve circuit. Science 334: 98-101, 2011.

ROSAS-BALLINA M, VALDES-FERRER SI, DANCHO ME, OCHANI M, KATZ D, CHENG KF, OLOFSSON PS, CHAVAN SS, AL-ABED Y, TRACEY KJ, PAVLOV VA: Xanomeline suppresses excessive proinflammatory cytokine responses through neural signal-mediated pathways and improves survival in lethal inflammation. Brain Behav Immun 44: 19-27, 2015.

SLOAN RP, MCCREATH H, TRACEY KJ, SIDNEY S, LIU K, SEEMAN T: RR interval variability is inversely related to inflammatory markers: the CARDIA study. Mol Med 13: 178-184, 2007.

TATEISHI Y, ODA S, NAKAMURA M, WATANABE K, KUWAKI T, MORIGUCHI T, HIRASAWA H: Depressed heart rate variability is associated with high IL-6 blood level and decline in the blood pressure in septic patients. Shock 28: 549-553, 2007.

TONHAJZEROVA I, MOKRA D, VISNOVCOVA Z: Vagal function indexed by respiratory sinus arrhythmia and cholinergic anti-inflammatory pathway. Respir Physiol Neurobiol 187: 78-81, 2013.

TORRES-ROSAS R, YEHIA G, PENA G, MISHRA P, DEL ROCIO THOMPSON-BONILLA M, MORENOEUTIMIO MA, ARRIAGA-PIZANO LA, ISIBASI A, ULLOA L: Dopamine mediates vagal modulation of the immune system by electroacupuncture. Nat Med 20: 291-295, 2014.

TRACEY KJ: The inflammatory reflex. Nature 420: 853-859, 2002.

VAN WESTERLOO DJ, GIEBELEN IA, FLORQUIN S, DAALHUISEN J, BRUNO MJ, DE VOS AF, TRACEY KJ, VAN DER POLL T: The cholinergic anti-inflammatory pathway regulates the host response during septic peritonitis. J Infect Dis 191: 2138-2148, 2005.

VON KÄNEL R, NELESEN RA, MILLS PJ, ZIEGLER MG, DIMSDALE JE: Relationship between heart rate variability, interleukin-6, and soluble tissue factor in healthy subjects. Brain Behav Immun 22: 461-468, 2008.

VISNOVCOVA Z, MOKRA D, MIKOLKA P, MESTANIK M, JURKO A, JAVORKA M, CALKOVSKA A, TONHAJZEROVA I: Alterations in vagal-immune pathway in long-lasting mental stress. Adv Exp Med Biol 832: 45-50, 2015.

WANG H, YU M, OCHANI M, AMELLA CA, TANOVIC M, SUSARLA S, LI JH, WANG H, YANG H, ULLOA L, AL-ABED Y, CZURA CJ, TRACEY KJ: Nicotinicacetylcholine receptor alpha7 subunit is an essential regulator of inflammation. Nature 421: 384-388, 2003.

WATKINS LR, MAIER SF, GOEHLER LE: Cytokine-to-brain communication: a review \& analysis of alternative mechanisms. Life Sci 57: 1011-1026, 1995.

WEBER CS, THAYER JF, RUDAT M, WIRTZ PH, ZIMMERMANN-VIEHOFF F, THOMAS A, PERSCHEL FH, ARCK PC, DETER HC: Low vagal tone is associated with impaired post stress recovery of cardiovascular, endocrine, and immune markers. Eur J Appl Physiol 109: 201-211, 2010.

YEBOAH MM, XUE X, DUAN B, OCHANI M, TRACEY KJ, SUSIN M, METZ CN: Cholinergic agonists attenuate renal ischemia-reperfusion injury in rats. Kidney Int 74: 62-69, 2008.

ZILA I, MOKRA D, KOPINCOVA J, KOLOMAZNIK M, JAVORKA M, CALKOVSKA A: Heart rate variability and inflammatory response in rats with lipopolysaccharide-induced endotoxemia. Physiol Res 64 (Suppl 5): S669-S676, 2015. 